\title{
Investigating the Contributing Factors Affecting High School Students' Self-confidence and the Solutions for Enhancement: A Case Study of Arabu Qala High School, Kandahar, Afghanistan
}

\author{
Abdullah Rahimi \\ English Language and Literature Department \\ Education Faculty \\ Kandahar University \\ Kandahar, Afghanistan \\ E-mail:abdullahhaidari365615@gmail.com
}

\begin{abstract}
This research paper examines the contributing factors affecting high school students' self-confidence and the solutions to enhance students' self-confidence. The study used quantitative approach, the researcher conducted a survey study by developing a questionnaire comprising 20 items based on five Likerts scales. The data was collected from 100 high school students through random sampling which 75 were male and 25 females. The data was analysed and interpreted in terms of mean and standard deviation through SPSS software (24) version. It was concluded that different factors like, students' feeling depressed, fear of making a mistake and others' much focus toward students affected their self-confidence. On the other hand, factors like, teachers' humor, students' feeling a sense of pride and students' encouragement and support from teachers' side could enhance their self-confidence.
\end{abstract}

Keywords: high school students, self-confidence, Kandahar

\section{Introduction}

In general, education nowadays has become a prominent thing as it involves most people to take part in this matter. In addition, it cannot be separated from human's life. Both males and females need to be educated. They have the same right to get education as much as they want because there is no limitation for education. No matter how old a person is, he / she can still get education during the rest of their lives. Hence, there is no such thing as too late to get education. Education is the only bridge that leads people to their better futures (Johan \& Harlan, 2014). Besides, education department has the major role to fix the student's belief on his/her own self, to perform a task at a particular level in order to have attention to a specific academic goal and it can be possible to hire the professional teachers based on psychological experience (Sander \& Sanders, 2005). Likewise, the child who perceives himself confident has a high level of academic achievement. The researcher further stated that the child who perceives himself as a worthless is less confident and may not come up to his optimum level (Eccles \& Wigfield, 2002).

Confidence is believed to effect performance through the influence on task perception. For example, high confidence creates a feeling of calmness when approaching a difficult task. Low confidence on the other hand, may result in an individual perceiving a task more difficult than it really is, which leads to stress and nervousness of ideas when taking the solution of the problem (Cole \& Kinzie, 2008). Related to self-confidence, Ozbey (2004) mentioned that self-confidence is defined an individual's recognition of his own abilities, loving himself and being aware of his own emotions. Furthermore, students with low self-confidence enter college with lower academic skills and are found to be less engaged and face more transition difficulties (Sander \& Sanders, 2005). In addition, individuals who are successful at school are in the habit of good work and these individuals are also interested in school and they are confident (Tamel \& Askoy, 2001). Moreover, school has been thought to play an important role in developing confidence, while studying at school, students need to communicate effectively with their friends and others strangers in high level confidence specially high school students to be successful in their academic life (Koc \& Polat, 2006). According to Mutluer (2006) who stated that self-confidence does not mean that a person will be happy despite all challenging conditions. On the other hand, people who have high self-confidence have been 
thought to be active in new enterprises and to have position attitudes. Individuals who have low self-confidence have difficulties in making of their minds, taking responsibilities and communicating with other people (Rutledge, 2000). Regarding self-confidence, Bengtsson, Persson, \& Willenhag (2005) stated that a gender difference is evident that there is growing literature that men are more self-confident than women in exam situations. The overall effect is that students who repeatedly under estimate their performances can lose motivation for learning due to lack of selfconfidence. Similarly, students who over estimate their performances may be at a disadvantage as their over confidence may impede their motivation to learn new techniques (Stankov, Morony \& Lee, 2014). With regards to students' self-confidence, Tett (2000) explained that the students' self- confidence can change student if he/she enters into the academic environment and it involves giving learning opportunities to refine the students' academic skills. The researcher also stated that confident attitude, a belief and a faith in oneself and one's ideas are essential in getting ahead, but it should also be remembered that self-confidence grows with success that means it's desirable to develop those qualities within oneself that makes for success. Regarding self-confidence, Srivastava (2013) mentioned that self-confidence is one of the attitudes possessed by each individual who has a positive outlook on himself and his situation. Researcher also stated that, self-confidence is the belief in self and self-ability, a mental attitude that trusts or relies on oneself.

\subsection{Problem Statement}

Generally appears that students' self-confidence is really important and it is essential to be existed in students, specifically in high school students. However, there are more challenges that avoid students' self-confidence, such as shyness, nervousness, and no trust on his/her self. Thus, there are some barriers and difficulties of twelfth class students' self-confidence at Arabu Qala high school. Although the students are in high level (twelfth class) and they are under graduates, but still they are faced with weak self-confidence. A similar concern was revealed by Martin (2004) who found that for one particular sample of Indian students, a significant negative association did exist between grade level and the classification of self-confidence. The students in high levels were really weak regarding self-confidence and self-belief, and they had a weak moral against their responsibilities. There are very few studies conducted regarding students' self-confidence. Therefore, the researcher want to fill this gap.

\subsection{Significance of the study}

This study may help the Kandahar Education Department, In particular, Arabu Qala high school Department and those students who are faced self-confidence problems, to bring effective changes in this part (students' selfconfidence).

\subsection{Purpose of the study:}

The purpose of this study is to find out the challenges that prevent High school students' self-confidence and the solutions that enhance twelfth class students' low self-confidence at Arabu Qala high school.

\subsection{Research Objectives}

- To investigate the contributing factors that affect twelfth class students' self-confidence at Arabu Qala high school.

- To investigate the solutions that enhance twelfth class students' self-confidence at Arabu Qala high school.

\subsection{Research Questions}

- What are the contributing factors that affect twelfth class students' self-confidence at Arabu Qala high school?

- What are the solutions that enhance twelfth class students' self-confidence at Arabu Qala high school?

\section{Literature review}

Students' self-confidence is probably the ability of self-belief in learners wish to improve as soon as possible. There is a large volume of previous literature and ideas of scholars regarding students' self-confidence as following. The researcher covered two aspects of self-confidence. 1) Factors that affecting students' self-confidence 2) Factors that enhance students' self-confidence. 


\subsection{Factors that affect students' self-confidence}

Relating to students' self-confidence, Dhall \& Thukral (2009) investigated intelligence as related to self-confidence and academic achievement of school students. The result of the study revealed that intelligence is significantly and positively related with self-confidence and academic achievement. Similarly, conducted a comparative study on selfconfidence of rural and urban students studying in $8^{\text {th }}$ standard of various schools of Amravati. It was found that, the average self-confidence of rural and urban, boys and girls are almost same and the rural boys were superior in their self-confidence in comparison to rural girls. The self-confidence of both sexes from urban are found almost same (Wankhade, Rokade \& Meena, 2011).

According to previous literature, Selvaraj \& Gnanadevan (2014) revealed that there is a significant and negative relationship between self-confidence and different dimensions of stress such as, academic stress, interpersonal stress, intrapersonal stress, environmental stress and total stress. In addition, the impact of sources of confidence on self-efficacy beliefs and academic achievement in the concept of Bandura's self-efficacy theory. The results revealed that, learning disability status had indirect influence on self-confidence via the source variable, gender did not have direct or indirect influences on self-confidence, and sources of confidence had direct impact on selfconfidence, which in turn affected academic performance (Hampton \& Mason, 2003). Likewise, Suzuki \& Tomoda (2015) who found that, early life stress in children, because of lack of care, reduces child's self-confidence and safely bond that it has with his parents and is likely for child to have depression in the future. In this study, stressful events are considered maltreatment, parental illness, death and sociopathic behaviors. All these facts reinforce to avoid behavior as well as insecure. As a result, children which have experienced these stressful events have low selfconfidence and are possible to have depressive signals. Regarding self-confidence, lots of researches have been shown that low self-confidence is associated with mood disorders and depression. In particular, Carter \& Garber (2011) had shown that, low self-confidence and low self-worth are associated with stress and depression. Both of them, constitute risk factors for appearance of depression, as people cannot manage and cope with the stressful life events. Furthermore, another study, investigated that, successfully coping with anxiety, depressiveness, and stressful situations may contribute to high levels of self-esteem and self-confidence. The results in the present study show that anxiety and depression partially effects on self-confidence (Nima, Rosenberg, Archer, \& Garcia, 2013).

According to Rubio (2007) who had shown that low self-confidence may lead to some psychological conditions such as sense of insecurity, fear, anxiety, and antisocial behaviors. This may be the case in learning too. At least, due to low self-confidence, the student will not be able to make a good start in learning, because low self-confidence affects students' learning motivation. Similarly, an individual who lacks in self-confidence will most probably have a negative bias towards the course and the classroom. A student will have always negative feelings like fear of failure, being inadequate, fear of making fun, and anxiety towards the teacher and course during the class, and avoid from speaking and participating in classroom activities (Bong, 2008). Furthermore, Obidigbo (2006) revealed that as a child, parents are the biggest influence on self-confidence. Children who are consistently criticized, threatened, yelled at or beaten by a parent quickly learn they are worthless. If children are continually ignored, teased or ridiculed at home or at school or if they are expected to be perfect all the time in order to be accepted at home or at school, they will eventually develop a poor selfimage. Regarding students' self-confidence, Stankov, Morony \& Lee (2014) had shown that, the overall effect is that students who repeatedly under estimate their performance can lose motivation for learning due to a lack of self-confidence. Similarly, students who over estimate their performance may be at a disadvantage as their over confidence may impede their motivation to learn new techniques. In addition, socio economic status and parents' education had significant effects on students' overall academic confidence scores. The researcher also mentioned that these two factors have a big impact on school students' self-confidence particularly, high school students (Farooq, Chaudhary, Shafiq \& Berhanu, 2011).

In terms of previous literature, Schramla, Perskia, Grossia \& Simonsson-Sarnecki. (2011) examined, three major groups of stress- related factors, namely, adolescent subjective psychosocial conditions, lifestyle, and selfconfidence. The results of this study showed that a substantial number of high school students, especially females, feel stressed and psychologically burdened. Furthermore, it was shown that highly stressed individuals, are more likely to feel worse about themselves, base their self-esteem on performance, and have more sleep problems as compared to non-stressed individuals. Compared to male students, the females not only reported significantly more stress signals but, lower global self-confidence, and higher performance-based self-confidence in females was also reported. Furthermore, the factors that affect undergraduate female students in confidence, performance, attitudes, and experience in undergraduate education. Hence, women can face unique barriers that include negative 
stereotypes, negative influences and discrimination. In the past women have been faced with a lack of role models, lack of encouragement and insufficient opportunities to succeed in education (Stoilescu \& McDougall, 2011). Relating to students' self-confidence, Rhee, Pan, Norman, Crow, \& Boutelle (2013) revealed that controlling parenting behaviors can have negative consequences for child self-confidence while more accepting parenting behaviors may help children utilize healthier eating practices when feeling stressed. This study suggested that controlling parenting behaviors decrease child self-confidence and self-esteem to engage in healthy eating behaviors during difficult emotional situations. Likewise, Rubio (2007) had shown that cognition is the center of selfconfidence, that success or failure is felt cognitively. This brings us to the conclusion that self-confidence is a sense (cognitive) just like anxiety and fear in humans. Many different factors may lead to anxiety and fear decrease selfconfidence.

\subsection{Factors that enhance students' self-confidence}

According to Parachin (2003) who found that there are seven key steps for developing self-confidence: 1- Begin the task with certainty, 2- Accept responsibility, 3- not let what you speak make you weak, 4- Take the bravery, 5Reject negative advice, 6- Follow the positive voices, and 7- Make anxiety omit. Moreover, collaborative learning really emphasizes students to actively participate in joint tasks. This will certainly make students better understand the concepts they are learning and can develop student self-confidence. In addition, students in the group decide and find out for themselves how they are solving a problem, task, or product without direct direction from the teacher, and find the sense of self-belief on his/herself (Laal \& Laal, 2011). On the other hand, Aggarwal \& Mishra (2005) found that demand, symbolic reward love, motivation and object reward affects the self-confidence of students significantly, and it can improve students' self-belief on his/herself as soon as we want. Despite, make the individual feels the excellence and success, improves self-confidence and raises self-belief level, whereas, success makes the individual feels proud and confident of his potentials and abilities, and that he is able to succeed and make achievement, and that such impact is a mutual one. The need to self-actualization is the top priorities of human needs and it is materialized on the education level through the need of the learner to obtain a high social rank (Al Hamaoui, 2010).

Furthermore, Ziegler \& Heller (2000) reported that girls expressed significantly lower levels of self-confidence than boys. There are various factors which have favorable impact on self-confidence of students. Cognitive Style, problem solving ability and educational aspiration are the important ones which also affect self-confidence of school students. Likewise, the enhancement of self-confidence is influenced by some factors such as, life experiences, parents, siblings, friends, and teachers. From them, the individual learn how to think about him/herself and the world around him/her. It is the support and encouragement individuals receive from the people around them or the lack of it that helps shape their inner feelings about themselves. A nurturing environment that provides positive feedback improves self-confidence. Hence, there is a need of environment support and more speaking practice in order to gain the students' self-confidence (Bitterlin, 2011). Al-Hebaish (2012) demonstrated that the sources of building selfconfidence points to self-confidence being derived from several factors. The most important factors are: (1) personal experiences. Successful experiences increase the development of high self-confidence, while the experiences of failure have the opposite effect, (2) social messages received from others. Community, home, school, and peers are important for self-confidence growth. In addition, self-confidence is developed during the age of childhood and shows from the accumulation of inter and intrapersonal experiences (Harris, 2009). Moreover, Rhee, Pan, Norman, Crow, \& Boutelle (2013) found that, parents may play an important role in preventing emotional destruction in children by promoting Self-efficacy (belief or confidence in one's ability) to eat healthily during stressful situations.

With regards to enhancing self-confidence, Caldwell, Horrison, Adams, Quin \& Greeson (2010) revealed that meditation helps students improve their self-confidence. Students' meditation is helpful for increasing self regulation, calming themselves, relieving stress, increasing relaxation, and improving emotional coping. In addition, students reported knowing themselves better and increased abilities to pay attention and to control thinking. Meditation can also be taught as a method of self-care as it has been shown to be an effective stress reliever. Furthermore, self-enhancing humor has a humorous outlook on life which is utilized to maintain self-confidence and cope with stress and pressure. The self-moral humor style is one of particular interest because it was found to have a strong and positive correlations with self-belief, and researchers suggesting that, this humor style tends to be used by individuals' experiencing psychological distress (Stieger, Formann, \& Burger, 2011). Related to development of students' self-confidence, Husainay (2004) demonstrated that, physical training refers to all outdoor activities, such as jungle tracking, canoeing, abseiling, flying fox and other physical activities, which require high power, physical 
and mental strength, may has a major role in enhancing self-confidence of an individual. Conversely, communication among individuals in classroom brings success faster than any material and technique, and can improve their self-confidence. A good communication with students is an achievement of self-confidence success for high school students. Only self-confident students can achieve this success. Self-confident students feel comfortable in classroom, and can present their messages to other students in the class (Arnold, 2007).

According to improvement of self- confidence, Bandura (2006) demonstrated that Encouraging students to act and speak correctly, giving them feedbacks especially, positive feedbacks and offering them in-class activities they will enjoy and can improve their self-confidence. Therefore, a student's sense of self-confidence can be promoted by other students' sense of self-confidence in classroom with those students that they are higher in self-confidence. In addition, Ewald (2007) reported that, only about half of the students in her study claimed to experience a relative level of confidence in their upper-level classes. The researcher revealed that even more surprising is that, only 12 of the students out of 21 reported they feel more confident now about their learning ability than ever before. The researcher then suggested that teachers work actively is useful to build upper level students' confidence and selfperception. In other words, when students do something correctly, tell them well-done and convince them to avoid the challenges and barriers of their self-belief. Meanwhile, Juhana (2012) mentioned that solution for lack of self-confidence to overcome those psychological factors, most students believed that motivating them to be more confident in the class is worth considering. This finding suggests that the teachers should be more aware of the obstacle of their students using activities and oral presentation in the class. On the other hand, teachers need to take the time to teach the students how to work in groups and how to communicate their ideas. Students may not know how to help effectively and may require special training to learn how to elaborate their thinking in order, to increase their confidence (Blumenfeld, Marx, Soloway, \& Krajcik 1996). Despite, giving students several strategies to use to help them determine what will be most effect to solve their problems. Students should get ways of thinking, habits of persistence and confidence in unfamiliar situations that will serve them well outside the classroom (National Council of Teachers of Mathematics, 2000).

\section{Material and Method}

\subsection{Research Design}

This research was quantitatively conducted. According to Fraenke, Wallen \& Hyun (2016), in a survey method, the researchers collects information from a large group of participants through their responses to the questionnaire items. The researchers added that quantitative study essentially tries to explain the problem using numbers and attempts to generalize the study from a larger population. The aim of the study is to investigate the contributing factors affecting high school students' self-confidence and the solutions for enhancement: A case study of Arabu Qala high school, Kandahar, Afghanistan. In general, case study is the preferred strategy when the investigator has little control over events, "how" or "why" questions are being posed and when the focus is on contemporary phenomenon within some real life context (Yin, 1998).

\subsection{Research site}

Arabu Qala high school was selected as the data collection source because it is one of the biggest schools of Kandahar city and also many students from different places come here for getting their education.

\subsection{Population and Sampling}

The population for this study was selected students from 12th grades and the total population of the study was four twelfth classes which consist 140 students. Then the researcher selected the sample 100 students based on the formula of (Krejcie \& Morgan, 1970). Among which 75 are males and 25 are females. Participants were all aged between 15 to 30 years old. Participants were selected through random sampling in this study, and from each class 25 students were selected to participate. The random sampling technique helped the researcher to ensure every respondent in the sample had an equal chance of being selected (Gravetter \& Forzano, 2006).

\subsection{Instrument}

The main instrument used in this survey study was a questionnaire. The researcher adopted and adapted questionnaire from different articles of (Ciarrochi, Heaven \& Fiona, 2007) and (Rosenberg, 1965). The 
questionnaire had three parts Part: A demographic information, Part: B there were 10 items related to challenges affecting students' self-confidence and Part C: were 10 items related to solutions that enhance students' selfconfidence based on 5 likert scales. 1- Strongly Agree 2- Agree 3- Undecided 4-Disagree 5Strongly Disagree.

\subsection{Questionnaire validity and reliability}

Concerning the validity of the questionnaire, the researcher shared the questionnaire with supervisor and received effective feedback. Also the researcher measured and checked the reliability of the questionnaire through (SPSS) software (24) version. As a result, the consistency of the questionnaire and items' scales was (0.70) Cronbach Alpha, which means that the scales and items were reliable. The general reliability values between .75 and 1.00 considered excellent, .60-.74 good, .40- .59 fair and below .40 is poor (Madhan \& Kensinger, 2017).

\subsection{Data Collection Procedure}

The researcher has collected the data through questionnaire in one week and participants were invited to participate and find out the relevant factors. As the participants were from school, it was necessary to translate the questionnaire by Pashto. First, the researcher took the permission from the Education Department, then from the head of school to collect the data. Then, the researcher went to the classes introduced himself, explained the questionnaire to the participants and described the aim of the study for conducting this research, and all the participants (Male and Female) were willing to participate in this study.

\subsection{Data Analysis}

After collecting the data from participants, the data was analyzed in order to know the result of the research. The analysis process was held with the help of SPSS software (24) version. Data was analyzed through different aspects regarding to the contributing factors of students' self-confidence based on Mean and Standard Deviation.

\section{Result and Findings}

\section{Characteristics of the respondents}

Table $\mathbf{- 1}$ shows the demographic information of the respondents in categories of gender, age and shift.

\begin{tabular}{llcc}
\hline Characteristics & & \multicolumn{1}{c}{$\begin{array}{c}\text { No. of } \\
\text { Respondents }\end{array}$} & Percentage \\
\hline Gender: & Male & 75 & 75 \\
\hline & Female & 25 & 25 \\
\hline Age: & $15-20$ & 77 & 77 \\
\cline { 2 - 4 } & $21-25$ & 16 & 16 \\
\cline { 2 - 4 } & $26-30$ & 7 & 7 \\
\hline Shift: & Morning & 25 & 50 \\
\cline { 2 - 4 } & Afternoon & 50 & 25 \\
\cline { 2 - 4 } & Night & 25 & 25 \\
\hline
\end{tabular}

Table-1 Shows that there were hundred participants. Out of hundred, 75 were male and 25 female students. Depending to their age, 15-20 years old were 77, 21-25 years old16, and 26-30 years old were7 students. Regarding to shift (term) 25 students were from Morning shift, 50 students from Afternoon shift and 25 students from Night shift.

Research question1: What are the contributing factors that affect twelfth class students' self-confidence at Arabu Qala high school? 
Table -2 Indicates the contributing factors affecting twelfth class students' self-confidence at Arabu Qala High school.

\begin{tabular}{llc}
\hline Factors that Affect Students' Self-confidence & $\begin{array}{c}\text { Mean } \\
\text { Standard } \\
\text { Dev. }\end{array}$ & 4.19 \\
\hline I often tend to think negatively in the class. & 3.62 & 1.23 \\
\hline I think that others don't respect me in the class. & 3.49 & 1.45 \\
\hline I am usually anxious and fearful in the class. & 3.45 & 3.52 \\
\hline I am very concerned about my appearance in the class. & 3.36 & 1.54 \\
\hline I often feel in the class like I don't know the right thing to do or say. & 2.34 & 1.61 \\
\hline I am easily embarrassed in the class. & $2.16^{*}$ & 1.37 \\
\hline I am very fearful of criticism and rejection in the class. & $2.10^{*}$ & 1.41 \\
\hline I think others in the class are much focused towards me what I say or do. & $1.96^{*}$ \\
\hline I fear making a mistake in the class which others might notice. & 1.18 \\
\hline I often feel depressed in the class when I have done something wrong.
\end{tabular}

Likerts scales: 1=Strongly Agree, 2= Agree, 3=Undecided, 4=Disagree, and 5= Strongly Disagree.

Table -2 Represents the mean scores for the contributing factors that affect twelfth class students' self-confidence at Arabu Qala high school. All of the items had the mean scores between the ranges of one to four. The average level of the twelfth class students' self-confidence affecting factors was in the range of "Strongly agree" and "Disagree". Items which gained higher mean scores in this dimension were identified as "I often tend to think negatively in the class." $(\mathrm{M}=4.19, \mathrm{SD}=1.23)$, "I think that others don't respect me in the class." $(\mathrm{M}=3.62, \mathrm{SD}=1.47)$ and "I am usually anxious and fearful in the class." $(\mathrm{M}=3.49, \mathrm{SD}=1.45)$. On the other hand, the three items with comparative lower mean scores were "I think others in the class are much focused towards me what I say or do." $(\mathrm{M}=2.16, \mathrm{SD}=$ 1.30), "I fear making a mistake in the class which others might notice." $(\mathrm{M}=2.10, \mathrm{SD}=1.41)$ and "I often feel depressed in the class when I have done something wrong." $(\mathrm{M}=1.96, \mathrm{SD}=1.18)$. The result indicates that the major factors which has effect on twelfth students' self-confidence are: 1) when the students felt depressed in the class whenever they have done something wrong. 2) When the students fear making a mistake which others might notice. 3) When the students think that others in the class are much focused towards them what they say or perform.

Research question2: What are the solutions that enhance twelfth class students' self-confidence at Arabu Qala high school?

Table- 3 Indicates the contributing factors that enhance twelfth class students' self-confidence at Arabu Qala high school

\begin{tabular}{|c|c|c|}
\hline Factors that enhance students' self-confidence & Mean & Standard Dev. \\
\hline I am able to do things as other people do in the class. & 2.27 & 1.32 \\
\hline On the whole I am satisfied with myself in the class. & 2.13 & 1.20 \\
\hline I get courage and bravery from my peers in the class. & 2.09 & 1.27 \\
\hline I feel positive while being with one or more adults in my class. & 2.07 & 1.17 \\
\hline I feel that I have a number of good qualities in the class. & 2.06 & 1.30 \\
\hline My Class fellows respect my ideas in the class. & 2.01 & 1.26 \\
\hline I am confident that I will achieve the goals that I have set for myself in the class. & 1.98 & 1.12 \\
\hline My teacher continually encourages and supports me in the class. & $1.92 *$ & 1.26 \\
\hline I feel a sense of pride about my activity in the class. & $1.90 *$ & 1.00 \\
\hline My teacher has humor during the teaching in the class. & $1.85^{*}$ & 1.14 \\
\hline
\end{tabular}


Likerts scales: 1=Strongly Agree*, 2= Agree, 3=Undecided, 4=Disagree, and 5= Strongly Disagree.

Table-3 Shows the mean scores for the contributing factors that enhance twelfth class students' self-confidence at Arabu Qala high school. All of the items had the mean scores between the ranges of one to two. The average level of the twelfth class students' self-confidence enhancement was in the range of "Strongly agree "and "Agree". Items which gained higher mean scores in this dimension were identified as "I am able to do things as other people do in the class." $(\mathrm{M}=2.27, \mathrm{SD}=1.32)$, "On the whole I am satisfied with myself in the class." $(\mathrm{M}=2.13, \mathrm{SD}=1.20)$ and "I get courage and bravery from my peers in the class." $(\mathrm{M}=2.09, \mathrm{SD}=1.27)$. Meanwhile, the three items with comparative lower mean scores were "My teacher continually encourages and supports me in the class." (M=1.92, $\mathrm{SD}=1.26)$, "I feel a sense of pride about my activity in the class." $(\mathrm{M}=1.90, \mathrm{SD}=1.00)$ and "My teacher has humor during the teaching in the class." $(\mathrm{M}=1.85, \mathrm{SD}=1.14)$. The result indicates that the respondents are (strongly agree) and (agree) in all items of the questionnaire. As a result, the major factors that enhance twelfth class students' selfconfidence are: 1) when their teachers are humorous during the teaching. 2) When the students feel a sense of pride about their activities in the class. 3) When teachers continually encourage and support students in the class.

\section{Discussion}

After analyzing and interpreting the data, the result of the current study revealed that there were some barriers and challenges in terms of high school students' self-confidence. Participants identified that they feel depressed inside the class whenever they have done something wrong or false. It means when students perform an activity untrue thus, they feel unhappy and have a tension toward their activities. This finding is in agreement with the findings of Carter \& Garber (2011) who showed that low self-confidence and low self-worth are associated negatively with stress and depression. The researchers added that both of them are risky factors for self-confidence, as people cannot manage and cope with the stressful life events, and feel displeased and unhappy each time. Furthermore, the research finding also showed that students fear of making a mistake which others might notice their mistakes they have done. It specifies that students are fearful of committing an error which their classmates might notice and make fun of them. The students further mentioned that they think that others in the class are much focused towards them when they say or perform something. It indicates that the students have anxiety in front of other classmates inside the class when they say something or perform an activity so they think if they say or do something others will laugh at them. These findings are similar with Juvonen, Graham \& Schuster (2003) who asserted that students have anxiety in front of their classmates and worried about that what the classmates consider about their performances.

In addition, the current study also illustrated that there are some solutions that enhance and increase high school students' self-confidence and self-belief. The findings demonstrated that the students could be more self-confident whenever their teacher has humor during the teaching. It means that the students feel comfortable and believe on themselves if their teacher is humorous and a happy man. This finding is further supported by the idea of Stieger, Formann, \& Burger (2011) who revealed that humor has a good outlook on life which is utilized to maintain selfconfidence and cope with stress and pressure. The self-moral humor style is one of particular interest because it was found to have a strong and positive correlations with self-belief, and the researchers suggested that humor style tends to be used by individuals to avoid the challenges which has effect on self-belief. Moreover, finding of this study also indicated that students will be over confident when they feel a sense of pride about their activities they have performed in the class. It shows if students are proud of their activities and performances they did, it can increase and develop their self-confidence against their other class fellows and teacher inside the class. The students also stated that encouragement and support from the teacher side can also increase their confidence. It indicates that encouragement and assistance of the teacher can improve and enhance students' self-beliefs. If a teacher helps the students and encourages them, they will feel independent and will have a high level self-confidence. These findings are in line with Bitterlin (2011) who asserted that it is the support and encouragement that individuals receive from the people around them and helps shape their inner feelings about themselves. Hence, there is a need of environment support and encouragement in order to enhance students' self-confidence.

\subsection{Recommendations and Suggestion}

The current study suggests the Education Department to hire teachers that are psychological experienced and be qualified for increasing students' self-confidence. In addition, the current study recommends the Arabu Qala high school administration to play an important role for developing students' self-confidence by performing useful activities, and insist teachers to perform some activities to increase self-belief in students. Finally, the study strongly 
recommends the teachers to develop the activities in the class, having humor during teaching in the class, give a sense of pride to students when they do an activity and continually encourage and support the students. After all, the researcher suggests that further research should be done to investigate the other various aspects of students' selfconfidence obstacles and challenges which students are faced with, and to find out other factors that increase students' self-confidence.

\section{Conclusion}

The present study was designed to determine the contributing factors that affect high school students' selfconfidence and to find out the solutions for enhancement. In accordance with the previous literature, scholars mentioned that there were some factors that affect students' self-confidence. Such as, stress, learning disability, depression, anxiety, fear, and lack of encouragement and support. On the other hand, researchers found some factors that enhance students' self-confidence. For instance, giving sense of bravery, reward, motivation, students' feeling of pride, and teachers' humor during the teaching. Moreover, the study was conducted quantitatively by providing questionnaire through random sampling. Despite, the data was analyzed through SPSS software (24) version based on mean and standard deviation. As a result, the present study revealed that there were three major factors that affected high school students' self-confidence. Like, students' feeling depressed in the class when they have done something wrong, fear of making a mistake which others might notice in the class. And others' much focus toward them about what they say or do. In addition, the current study found that there are three contributing factors that could enhance high school students' self-confidence. Such as, teachers' humor during the teaching, students' feeling a sense of pride about their activities in class. And students' encouragement and support from teachers' side.

\section{Acknowledgement}

First, I am grateful and happy from the support of my dear respectable advisor Teaching Assistant Mr. Hashmatullah Tareen who helped me a lot in preparing this research paper. That was his helping and motivation which I completed my final formal activity at Kandahar University and also his support and encouragement is unforgettable. Secondly, I want to thank from dear Teaching Assistant Mr. Ahmad Zahir Wali who helped me in statistical analysis by the help of (SPSS) software. Finally, I thank from those participants participated in my study.

\section{References}

Aggarwal and Mishra, A.K. (2005). Impact of parent child relationship on self-confidence. Indian Journal PsychoEdu, 36, 146-152.1, 60-65.

Al Hamaoui, M. (2010) Academic achievement and its relation with self-concept, Damascus University, 26 , p. 176.

Al-Hebaish, S.M. (2012). The correlation between general self-confidence and academic achievement in the oral presentation course, Theory and practice in language studies, (2)

Arnold, J. (2007). "Self-Conceptandtheaffective domain in language learning, self-esteem and foreign language learning". Cambridge Scholars Publishing: Cambridge.

Bengtsoon, C, Persson, M. \& Willenhag, P. (2005). Genred and overconfidence. Economics letters, 86 (2), 199203. http://dx.doi.org/10.2016/j.econlet.2004.07.012

Bitterlin, G. (2011). Ventures transition workbook. New York: Cambridge University Press.

Blumenfeld, P., Marx, R., Soloway, E., \& Krajcik, J. (1996). Learning with peers: From small group cooperation to collaborative communities. Educational Researcher, 25, 37-40.

Bong, M. (2008). Effects of parent-child relationships and classroom goal structures on motivation, helpseeking avoid ance and cheating. J. Exp. Educ. 76(2):191-217

Bundura, A. (2006). Towards a psychology of human agency. Perspect.Psychol. Sci. 1(2):164180.

Caldwell, K., Harrison, M., Adams, M., Quin, R.H., \& Greeson, J. (2010). Developing Mindfulness in College Students through Movement Based Courses: Effects on Self-Regulatory Self-Efficacy, Mood, Stress, and Sleep Quality. Journal of American College Health, 58, 433-442.

Carter, J. S., \& Garber, J. (2011). Predictors of the First Onset of a Major Depressive Episode and Changes in Depressive Symptoms across Adolescence: Stress and Negative Cognitions. Journal of Abnormal Psychology, 120, 779-796. http://dx.doi.org/10.1037/a0025441

Ciarrochi, J., Heaven, P. C. L., \& Fiona, D. (2007). The impact of hope, self-esteem, and attributional style on adolescents' school grades and emotional well-being: A longitudinal study.

Cole, S. J. Kinzie, J. (2008) supporting the names of diverse learner: first year students' academic confidence and student engagements, Center for post-secondary research Indiana University. 
Dhall, S. and Thukral, P. (2009). Intelligence as related of self-confidence and academic achievement of school students. Journal of all India Association for Educational Research, 21(2).

Eccles, J. S. \& Wigfield, A. (2002). Self-concept, domain values, and self-esteem: Relations and changes at early adolescences. Journal of personality, 57(2), 283-310.

Ewald, J. D. (2007). Foreign language learning anxiety in upper-level classes: Involving students as researchers. Foreign Language Annals, 40(1), 122-142.

Farooq, M. S., Chaudhary, H. A., Shafiq, M. \& Berhanu, G. (2011) Factors affecting students' quality of academic performance: a case of secondary school level, Journal of quality and technology management, 2 (I7), 114.

Fraenkel. J. R, Wallen. N. E \& Hyun. H.H. (2016). How to design and Evaluate Research in Education (9th edition). New York: Mc Graw-Hill Education.

Gravetter, F.J., \& Forzano, L.B. (2006). Research Methods for the Behavioral Science Belmont, USA: Thomson Wadsworth.

Hampton, N.Z. and Mason, E. (2003). Learning disabilities, gender, sources of efficacy, self-efficacy beliefs, and academic achievement in high school students. Journal of School Psychology, 41(2), 101-112.

Harris, S. (2009). The relationship Between Self-Esteem and Academic Success among African American Students in the Minority Engineering Program at a Research Extensive University in the Southern Portion of the United States. Doctoral Dissertation. Louisiana State University.

Husainay, H., (2004) Malaysia Physical Training Manual. 1st Edn, Institut Kepimpinan Wawasan, Selangor Darul Ehsan.

Johan, R., \& Harlan, J. (2014). Education Nowadays. International Journal of Educational Science and Research (IJESR), 4(5), 51-56. Chicago

Juhana (2012). Psychological factors that hinder students from speaking in English class (A case study in a senior high school in South Tangerang, Banten, Indonesia). Journal of Education and practice. Vol. 3, No. 12, 2012.

Juvonen, J., Graham, S., \& Schuster, M. A. (2003). Bullying among young adolescents: The strong, the weak, and the troubled. Pediatrics, 112(6), 1231-1237.

Koc, M. \& Polat, U. ((2006) Universite ogrencilerinin ruh sagligi. Insan Bilimleri Dergisi, 3(2), 1-22.

Krejcie, R. V., \& Morgan, D. W. (1970). Determining sample size for research activities. Educational and psychological measurement, 30(3), 607-610.

Laal, M \& Laal, M. (2011). Collaborative Learning: What is it? Procedia-Social and Behavioral Sciences, 31 , 491 495.

Madan, C. R., \& Kensinger, E. A. (2017). Test-Retest Reliability of Brian Morphology Estimates. Brian Informatics, 4, 107-121.

Martin, G. N. (2004) Estimates of emotional and psychometric intelligence: Evidence for gender based stereotype. Journal of psychology, 144, 2, 149-162.

Mutluer, S. (2006) Ouzguven olasmasida manevi degerlerin Rolo, Master thesis, University of Ankara.

National Council of Teachers of Mathematics. (2000). Principles and standards for school mathematics. Reston, VA: Author.

Nima, A. A., Rosenberg, P., Archer, T., \& Garcia, D (2013). Anxiety, Affect, Self-Esteem, and Stress: Mediation and Mod-eration Effects on Depression. PLoS ONE, 8, e73265. http://dx.doi.org/10.1371/annotation/49e2c5c8-e8a8-4011-80fc-02c6724b2acc

Obidigbo, G.C.E. (2006). Fields of Psychology. Self-efficacy third edition Enugu: Sages comm.

Ozbey, C. (2004) Cocuk sorunlarina yapict Cozumler. Level of confidence a work book. Istanbul: Inkilap.

Parachin, V.M. (2003). Developing dynamic self-confidence. Super Vision, 64, 13-15

Rhee, K. E., Pan, T. Y., Norman, G. J., Crow, S., \& Boutelle, K. (2013). Relationship between Maternal Parenting and Eating Self-Efficacy in Overweight Children When Stressed. Eating and Weight Disorders-Studies on Anorexia, Bulimia and Obesity, 18, 283-288. http://dx.doi.org/10.1007/s40519-013- 0043-x

Rosenberg, M. (1965). Society and the adolescent self-image. Princeton, NJ: Princeton University Press.

Rubio F (2007). "Self-esteem and foreign language learning, introduction". Cambridge Scholars Publishing: Cambridge.

Rutledge, T. (2000). Earning your own respect: A hand book of personal responsibility (A. Cakiroglu, Trans). Istanbul: Karuldisi.

Sander, p \& Sander, L (2005) Giving presentation: The impact on students' perception. Psychological learning and Technology, 11 (1), 25-41. 
Schramla, K., Perskia, A., Grossia, G., \& Simonsson-Sarnecki, M. (2011). Stress Symptoms among Adolescents: The Role of Subjective Psychosocial Conditions, Lifestyle, and Self-Esteem. Journal of Adolescence, 34, 987-996. http://dx.doi.org/10.1016/j.adolescence.2010.11.010

Selvaraj, A., Gnanadevan, R. (2014). Self-confidence and stress among higher senior secondary students of Cuddalore District of Tamil Nadu. Journal of Community Guidence and Research, 31(1), 71-77.

Srivastava, S. K. (2013). To Study the Effect of Academic Achievement on the Level of Self-confident. J. Psychosoc. Res., Vol. 8, No. 1, 41-51

Stankov, L, Morony, S. \& Lee, Y. P. (2014) Cofidence: The best non-cognitive predicator of academic achievement? Educational psychology, 34(1), 9-28-http://dx.doi.org/10.1080/01443410.2013.814194

Stieger, S., Formann, A. K., \& Burger, C. (2011). Humor Styles and Their Relationship to Explicit and Implicit Self-Esteem. Personality and Individual Differences, 50, 747-750.

http://dx.doi.org/10.1016/j.paid.2010.11.025

Stoilescu, D. \& McDougall, D. (2011). Gender digital divide and challenges in undergraduate computer science programs. Canadian Journal of Education, 34(1), 308-333. http://www.cjerce.ca/index.php/cjerce/article/viewFile/461/866

Suzuki, H., \& Tomoda, A. (2015). Roles of Attachment and Self-Esteem: Impact of Early Life Stress on Depressive Symp-toms among Japanese Institutionalized Children. BMC Psychiatry, 15, 8.http://dx.doi.org/10.1186/s12888-015-0385-1

Tamel, Z. F, \& Askoy, B. A. (2001) Ergen ve gelisimi. Self-esteem a hand book. Ankara: Nobel.

Tett, 1. (2000) I am working class and proud of it-gendered experiences of non-traditional participants in higher education, Gender and education, 1 (2), 183-194.

Wankhade, N.A., Rokade, Meena, K. (2011). A comparative study of self-confidence of rural and urban students studying in standard VIII of various schools of Amravati District. Journal of Education and Psychology, 67(1), 36-38.

Yin, R. K. (1998). The abridged version of case study research: Design and method.

Ziegler, A. Heller, K. A. (2000). Conditions for self-confidence among boys and girls achieving highly in Chemistry. Journal of Secondary Gifted Education, 11(3), 144-151.

\section{About author}

- Name and Last name: Abdullah Rahimi

- F/name: Abdul Rahim

- Date of birth: 1995

- Place of birth: Kandahar

- Country: Afghanistan

- Province: Kandahar

- District: Gach Khanay

- Level of Education: Graduated student of B.A. degree

- University: Kandahar University

- Faculty and Department: Education Faculty, English Language and Literature Department

- Occupation: Teacher in Arabu Qala High school and ASREC-EC English Academy

- Phone: +93700365615

- E-mail: abdullahhaidari365615@gmail.com

\section{Copyrights}

Copyright for this article is retained by the author(s), with first publication rights granted to the journal.

This is an open-access article distributed under the terms and conditions of the Creative Commons Attribution license (http://creativecommons.org/licenses/by/4.0/) 